J. Dairy Sci. 95:7261-7268

http://dx.doi.org/10.3168/jds.2012-5582

(C) American Dairy Science Association ${ }^{\circledR}, 2012$.

\title{
Cow and herd variation in milk urea nitrogen concentrations in lactating dairy cattle ${ }^{1}$
}

\author{
M. Aguilar, ${ }^{\star}$ M. D. Hanigan, ${ }^{\star 2}$ H. A. Tucker,† B. L. Jones, ${ }^{\star}$ S. K. Garbade, ${ }^{*}$ M. L. McGilliard, ${ }^{*}$ C. C. Stallings, ${ }^{*}$ \\ K. F. Knowlton, ${ }^{\star}$ and R. E. James* \\ *Department of Dairy Science, Virginia Polytechnic Institute and State University, Blacksburg 24061 \\ †Department of Animal Sciences, Purdue University, West Lafayette, IN 47097
}

\begin{abstract}
Milk urea nitrogen (MUN) is correlated with $\mathrm{N}$ balance, $\mathrm{N}$ intake, and dietary $\mathrm{N}$ content, and thus is a good indicator of proper feeding management with respect to protein. It is commonly used to monitor feeding programs to achieve environmental goals; however, genetic diversity also exists among cows. It was hypothesized that phenotypic diversity among cows could bias feed management decisions when monitoring tools do not consider genetic diversity associated with MUN. The objective of the work was to evaluate the effect of cow and herd variation on MUN. Data from 2 previously published research trials and a field trial were subjected to multivariate regression analyses using a mixed model. Analyses of the research trial data showed that MUN concentrations could be predicted equally well from diet composition, milk yield, and milk components regardless of whether dry matter intake was included in the regression model. This indicated that cow and herd variation could be accurately estimated from field trial data when feed intake was not known. Milk urea $\mathrm{N}$ was correlated with dietary protein and neutral detergent fiber content, milk yield, milk protein content, and days in milk for both data sets. Cow was a highly significant determinant of MUN regardless of the data set used, and herd trended to significance for the field trial data. When all other variables were held constant, a percentage unit change in dietary protein concentration resulted in a $1.1 \mathrm{mg} / \mathrm{dL}$ change in MUN. Least squares means estimates of MUN concentrations across herds ranged from a low of $13.6 \mathrm{mg} / \mathrm{dL}$ to a high of $17.3 \mathrm{mg} / \mathrm{dL}$. If the observed MUN for the high
\end{abstract}

Received March 28, 2012.

Accepted August 19, 2012.

${ }^{1}$ This project was supported by the Maryland Department of Agriculture (Annapolis; grant MDA-1761-A2). Mention of any trademark or proprietary product in this paper does not constitute a guarantee or warranty of the product by the Maryland Department of Agriculture and does not imply its approval to the exclusion of other products that also may be suitable.

${ }^{2}$ Corresponding author: mhanigan@vt.edu herd were caused solely by high crude protein feeding, then the herd would have to reduce dietary protein to a concentration of $12.8 \%$ of dry matter to achieve a MUN concentration of $12 \mathrm{mg} / \mathrm{dL}$, likely resulting in lost milk production. If the observed phenotypic variation is due to genetic differences among cows, genetic choices could result in herds that exceed target values for MUN when adhering to best management practices, which is consistent with the trend for differences in MUN among herds.

Key words: milk urea nitrogen, feeding management, dairy cattle

\section{INTRODUCTION}

Nitrogen emissions from agriculture cause air and water quality impairment (Tamminga, 1992; Van Horn et al., 1996). Animal agriculture has been identified as a major contributor of $\mathrm{N}$ pollution to water resources in the Chesapeake Bay watershed (Fisher and Oppenheimer, 1991; Boesch et al., 2001), and research resources have focused on identifying management practices to reduce the environmental impact (NRC, 2003).

Dairy cattle are commonly fed diets with protein levels exceeding $16 \%$ to ensure maximum milk output (NRC, 2001). This practice contributes to the relatively low $\mathrm{N}$ efficiency of lactating dairy cattle (Bequette et al., 2003; Huhtanen and Hristov, 2009) while adding dietary cost and potentially decreasing profit margins (Godden et al., 2001). Milk urea nitrogen is highly correlated with urinary N excretion (Jonker et al., 1998; Kauffman and St-Pierre, 2001) and is a good indicator of $\mathrm{NH}_{3}$ emissions from dairy manure (Burgos et al., 2007).

Dietary protein available for microbial use in the rumen can be degraded to AA and peptides. These are utilized by microbes for microbial protein synthesis, or are deaminated and used to support energy needs (see Tamminga, 1979). Provision of ruminally available $\mathrm{N}$ in excess of microbial needs for protein synthesis results in the generation of $\mathrm{NH}_{3}$ that is absorbed and converted 
to urea in the liver (Parker et al., 1995). Absorbed AA and peptides provided in excess of animal requirements are also deaminated and converted to urea. Thus, urea synthesis is proportional to the balance of dietary $\mathrm{N}$ and the use of $\mathrm{N}$ for productive purposes.

Synthesized urea is released into the blood and equilibrates with body fluids, including milk (Broderick and Clayton, 1997; Archibeque, 2000). This results in high correlations of blood urea $\mathrm{N}$ and MUN with dietary $\mathrm{N}$ (Nousiainen et al., 2004, Preston et al., 1965). Because the kidney urea clearance is concentration dependent, a high correlation also exists between MUN and urinary N excretion (Jonker et al., 1998). These relationships and routine measurement of MUN by milk processors and DHIA testing laboratories have led to the use of MUN as a tool for monitoring feeding programs and feed management practices (NRCS, 2011).

Although MUN concentration is clearly related to $\mathrm{N}$ balance within a cow, several factors can cause deviations from expected values. These include time of sampling, season of the year, BW, breed, and nutritional factors (DePeters and Cant, 1992; Broderick and Clayton, 1997; Kauffman and St-Pierre, 2001). Significant cow effects (Wattiaux et al., 2005) are also at least partially explained by genetic variance (Wood et al., 2003; Mitchell et al., 2005; Miglior et al., 2007; Stoop et al., 2007). Given the genetic effects on MUN, it is possible that sire selection decisions within a herd may result in herd concentrations of MUN differing from the expected values based on feed management. When the model of Kauffman and St-Pierre (2001) was used to predict MUN concentrations for individual cows in trials performed by Cyriac et al. (2008) and Rius et al. (2010), the variance in residual MUN associated with the cow was $4.1 \pm 1.1 \mathrm{mg} / \mathrm{dL}(P<0.001)$, indicating that the cow itself was an important determinant of MUN. Because differences in DMI were accommodated in the model, DMI could be ruled out as a contributor to the observed cow variance. The model did not exhibit mean bias, although the range in residual errors (mean residual $=-0.1 \pm 6.5 \mathrm{mg} / \mathrm{dL}$ ) was large. If herd-level deviations are as large, it could result in poor feed management decisions when using MUN to guide feeding choices.

Studies examining genetic parameters for cow and herd variation in MUN have not used dietary information (Wood et al., 2003; Mitchell et al., 2005; Miglior et al., 2007; Stoop et al., 2007). Part of the cow and herd variance, therefore, may be associated with feeding multiple diets within a herd and differing diets across herds (Jonker et al., 1998; Kauffman and St-Pierre, 2001). Conversely, studies examining the relationships among dietary nutrients and MUN have not reported cow and herd variance. The objective of this study was to determine variation associated with animal and herd MUN levels while accounting for differences in dietary nutrient content, level of production, and stage of lactation. It was hypothesized that cow variation in MUN could affect overall herd MUN and bias feed management decisions.

\section{MATERIALS AND METHODS}

Intake, dietary nutrients, and production data from 2 previously published trials (Cyriac et al., 2008; Rius et al., 2010) were used to assess whether MUN could be predicted as well from dietary nutrient concentrations as from nutrient intakes. A total of 68 multiparous Holstein and 12 multiparous Jersey $\times$ Holstein crossbreds were included in the data set.

The first trial included observations from 40 midlactation cows randomly assigned to 1 of 4 diets that contained 11.3, 10.1, 8.8, or 7.6\% RDP (DM basis) with corresponding reductions in dietary $\mathrm{CP}$ (Cyriac et al., 2008). The second trial included observations from 40 midlactation cows assigned to 1 of 4 diets that contained high (1.55 Mcal of $\mathrm{NE}_{\mathrm{L}} / \mathrm{kg}$ ) or low dietary energy (LE, 1.44 Mcal of $\left.\mathrm{NE}_{\mathrm{L}} / \mathrm{kg}\right)$ and high (6.6\% RUP) or low ruminally undegraded protein (4.6\% RUP) arranged in a $2 \times 2$ factorial design (Rius et al., 2010). Feed samples were analyzed for total N (Perkin-Elmer 2410 Series II, Perkin-Elmer, Norwalk, CT), ether extract (AOAC International, 1996; method 920.39), ash (AOAC International, 1996; method 942.05), ADF (AOAC International, 1997), NDF (Van Soest et al., 1991), lignin (AOAC International, 1997), soluble CP (Licitrae et al., 1996), neutral detergent-insoluble CP (Licitra et al., 1996), acid detergent-insoluble CP (Licitra et al., 1996), starch (2700 Select Biochemistry Analyzer, YSI, Yellow Springs, OH), minerals (AOAC International, 1997), and gross energy (bomb calorimetry, model 1271, Parr Instruments, Moline, IL). A summary of the data are provided in Table 1.

A second analysis was performed using data from a field trial with 5 herds (predominantly Holstein) that were being intensively monitored for $\mathrm{P}$ feeding plus the Virginia Tech herd (Holstein, Jersey, and various crossbreeds of Holstein, Jersey, Brown Swiss, and Swedish Red). All herds used DHIA testing services, and each herd was feeding a single lactating cow ration. On 2 consecutive test dates, milk production was recorded and milk samples were analyzed for true protein, fat, and lactose by infrared analyses (Fossomatic 4000 Combi infrared analyzer; Foss, Eden Prairie, MN) and for MUN using a modification of the Berthelot procedure (ChemSpec 150 Analyzer; Bentley Instruments, Chaska, MN; DHIA, Blacksburg, VA). In total, data were collected from 741 cows. 
Table 1. A summary of intake, dietary nutrients, and production values for cows from the Cyriac et al. (2008) and Rius et al. (2010) experiments

\begin{tabular}{|c|c|c|c|c|}
\hline Variable & Mean & SD & Minimum & Maximum \\
\hline \multicolumn{5}{|c|}{ Intake $(\mathrm{kg} / \mathrm{d}, \mathrm{DM}$ basis $)$} \\
\hline DMI & 24.8 & 3.39 & 13.1 & 34.9 \\
\hline $\mathrm{N}$ & 0.68 & 0.14 & 0.29 & 1.03 \\
\hline $\mathrm{CP}$ & 4.23 & 0.89 & 1.78 & 6.45 \\
\hline $\mathrm{NDF}$ & 9.52 & 2.05 & 4.65 & 17.7 \\
\hline $\mathrm{ADF}$ & 6.11 & 1.41 & 2.99 & 12.3 \\
\hline Starch & 5.97 & 1.12 & 3.32 & 8.31 \\
\hline Ash & 1.49 & 0.28 & 0.91 & 2.23 \\
\hline DIM & 175 & 71.3 & 35 & 413 \\
\hline $\operatorname{Milk}(\mathrm{kg} / \mathrm{d})$ & 36.9 & 8.53 & 12.6 & 60.7 \\
\hline Milk fat $(\%)$ & 3.48 & 0.61 & 2.15 & 5.72 \\
\hline Milk protein (\%) & 3.08 & 0.27 & 2.54 & 4.03 \\
\hline Milk lactose (\%) & 4.89 & 0.21 & 4.06 & 5.26 \\
\hline MUN (mg/dL) & 17.9 & 4.06 & 9.68 & 29.15 \\
\hline \multicolumn{5}{|c|}{ Dietary nutrient (\% of DM) } \\
\hline $\mathrm{DM}$ & 51.4 & 2.15 & 47.9 & 53.9 \\
\hline $\mathrm{CP}$ & 16.9 & 2.31 & 13.6 & 19.9 \\
\hline NDF & 38.3 & 5.69 & 31.4 & 50.7 \\
\hline $\mathrm{ADF}$ & 24.5 & 4.09 & 18.6 & 35.2 \\
\hline Starch & 24.1 & 3.39 & 14.8 & 28.8 \\
\hline Ash & 6.05 & 0.88 & 4.92 & 7.20 \\
\hline
\end{tabular}

Samples of the TMR were collected for the 5 herds on the $\mathrm{P}$ project, and ingredients used in the ration were sampled at the Virginia Tech herd. All samples were submitted to Cumberland Valley Analytical Services (Hagerstown, MD) for analyses of total N, NDF, ADF, and ash. Nitrogen was analyzed according to method 990.03 (AOAC International, 2000), whereas NDF, $\mathrm{ADF}$, and ash were analyzed using methods noted previously. Dietary $\mathrm{NE}_{\mathrm{L}}$ was predicted from the other nutrients. Dietary nutrient concentrations were calculated for the Virginia Tech herd based on ingredient analyses and dietary inclusion rates. A summary of the data are provided in Table 2.

Regression analyses were performed using the Mixed procedure of SAS (version 9.2; SAS Institute Inc., Cary, $\mathrm{NC}$ ). Two models were used for analyses of the research trial data. The first model regressed MUN concentra- tions on intakes of $\mathrm{CP}, \mathrm{NDF}, \mathrm{ADF}$, and starch (DM basis), DIM, milk yield, milk composition, milk component yield, SCC, period, experiment, and BW, and all 2-way interactions of these terms. The second model regressed MUN concentrations on dietary concentrations of $\mathrm{CP}, \mathrm{NDF}, \mathrm{ADF}$, and starch, DIM, milk yield, milk composition, milk component yield, SCC, period, experiment, and BW, and all 2-way interactions. Variables with $P$-values greater than 0.1 were sequentially excluded from models by using a backward elimination procedure. Cow was included as a random variable, and the effect of cow was tested using a Covtest statement.

Field trial data were analyzed in the same manner using the Mixed procedure of SAS (version 9.2; SAS Institute Inc.). Milk urea nitrogen was regressed on dietary concentrations of $\mathrm{CP}, \mathrm{ADF}$, and $\mathrm{NDF}$ (\% of DM), dietary $\mathrm{NE}_{\mathrm{L}}(\mathrm{Mcal} / \mathrm{kg}$ of DM), DIM, milk yield $(\mathrm{kg} / \mathrm{d})$,

Table 2. A summary of production and dietary factors for field trial cows

\begin{tabular}{|c|c|c|c|c|}
\hline Variable & Mean & $\mathrm{SD}$ & Minimum & Maximum \\
\hline DIM & 198 & 157 & 2 & 977 \\
\hline Milk (kg/d) & 37.8 & 10.0 & 7.4 & 78.6 \\
\hline Milk fat (\%) & 3.76 & 0.88 & 1.5 & 8.5 \\
\hline Milk protein (\%) & 3.04 & 0.34 & 2.2 & 5.6 \\
\hline MUN (mg/dL) & 15.5 & 3.9 & 4 & 35 \\
\hline \multicolumn{5}{|c|}{ Dietary nutrient (\% of DM) } \\
\hline $\mathrm{DM}$ & 48.9 & 4.7 & 43.4 & 57.8 \\
\hline $\mathrm{CP}$ & 17.6 & 1.6 & 14.4 & 23.4 \\
\hline $\mathrm{NDF}$ & 35.3 & 3.4 & 30.5 & 41.5 \\
\hline $\mathrm{ADF}$ & 21.2 & 2.4 & 17.6 & 25.5 \\
\hline Ash & 7.1 & 0.6 & 6.0 & 9.7 \\
\hline $\mathrm{NE}_{\mathrm{L}}(\mathrm{Mcal} / \mathrm{kg})$ & 1.68 & 0.06 & 1.54 & 1.75 \\
\hline
\end{tabular}


Table 3. Parameter estimates for a mixed model relating MUN (mg/dL) to nutrient intake, production, and cow factors for the trials summarized in Table 1

\begin{tabular}{|c|c|c|c|}
\hline Item & Estimate & $\mathrm{SE}$ & $P$-value \\
\hline \multicolumn{4}{|l|}{ Effect } \\
\hline Intercept & 6.89 & 6.76 & $<0.31$ \\
\hline ADF intake $(\mathrm{kg} / \mathrm{d})$ & -6.38 & 1.47 & $<0.0001$ \\
\hline $\mathrm{CP}$ intake $(\mathrm{kg} / \mathrm{d})$ & 20.3 & 2.50 & $<0.0001$ \\
\hline Starch intake $(\mathrm{kg} / \mathrm{d})$ & -4.73 & 1.89 & $<0.02$ \\
\hline Milk yield $(\mathrm{kg} / \mathrm{d})$ & -0.33 & 0.14 & $<0.03$ \\
\hline Milk protein yield $(\mathrm{kg} / \mathrm{d})$ & 5.35 & 3.16 & $<0.09$ \\
\hline $\mathrm{SCC}(\times 1,000)$ & -0.002 & 0.0009 & $<0.01$ \\
\hline ADF intake $(\mathrm{kg} / \mathrm{d}) \times$ milk lactose yield $(\mathrm{kg} / \mathrm{d})$ & 1.54 & 0.69 & $<0.03$ \\
\hline ADF intake $(\mathrm{kg} / \mathrm{d}) \times$ milk fat yield $(\mathrm{kg} / \mathrm{d})$ & 14.7 & 4.25 & $<0.001$ \\
\hline ADF intake $(\mathrm{kg} / \mathrm{d}) \times \mathrm{DIM}$ & 0.04 & 0.02 & $<0.02$ \\
\hline $\mathrm{CP}$ intake $(\mathrm{kg} / \mathrm{d}) \times$ starch intake $(\mathrm{kg} / \mathrm{d})$ & -1.33 & 0.36 & $<0.0005$ \\
\hline $\mathrm{CP}$ intake $(\mathrm{kg} / \mathrm{d}) \times$ milk lactose yield $(\mathrm{kg} / \mathrm{d})$ & -2.93 & 1.08 & $<0.009$ \\
\hline $\mathrm{CP}$ intake $(\mathrm{kg} / \mathrm{d}) \times \mathrm{DIM}$ & -0.01 & 0.005 & $<0.04$ \\
\hline NDF intake $(\mathrm{kg} / \mathrm{d}) \times$ starch intake $(\mathrm{kg} / \mathrm{d})$ & 2.02 & 0.71 & $<0.006$ \\
\hline NDF intake $(\mathrm{kg} / \mathrm{d}) \times$ milk fat yield $(\mathrm{kg} / \mathrm{d})$ & -10.5 & 2.99 & $<0.0008$ \\
\hline NDF intake $(\mathrm{kg} / \mathrm{d}) \times$ DIM & -0.03 & 0.01 & $<0.03$ \\
\hline Starch intake $(\mathrm{kg} / \mathrm{d}) \times \mathrm{ADF}$ intake $(\mathrm{kg} / \mathrm{d})$ & -2.62 & 1.04 & $<0.01$ \\
\hline Starch intake $(\mathrm{kg} / \mathrm{d}) \times$ milk lactose yield $(\mathrm{kg} / \mathrm{d})$ & 1.25 & 0.72 & $<0.09$ \\
\hline Starch intake $(\mathrm{kg} / \mathrm{d}) \times$ milk fat yield $(\mathrm{kg} / \mathrm{d})$ & 2.12 & 0.72 & $<0.004$ \\
\hline Starch intake $(\mathrm{kg} / \mathrm{d}) \times \mathrm{DIM}$ & 0.01 & 0.004 & $<0.0007$ \\
\hline \multicolumn{4}{|l|}{ Random effect } \\
\hline Cow & & & $<0.0004$ \\
\hline Model precision $^{1}$ & & & Value \\
\hline $\mathrm{AIC}$ & & & 750 \\
\hline RMSE & & & 1.77 \\
\hline
\end{tabular}

${ }^{1} \mathrm{AIC}=$ Akaike information criterion; RMSE $=$ root mean square error.

milk protein (\%), and all 2-way interactions. Herd and cow nested within herd were included as random variables in the model. The effects of cow and herd were tested using a Covtest statement.

\section{RESULTS}

Results from analyses of the research trial data using models 1 and 2 are presented in Tables 3 and 4, respectively. When nutrient intakes were included in the regression model, MUN was correlated with intakes of $\mathrm{ADF}, \mathrm{CP}$, and starch; interactions of $\mathrm{ADF}, \mathrm{CP}, \mathrm{NDF}$, and starch intakes; milk yield, milk protein yield, SCC; interactions of ADF intake with milk lactose yield, milk fat yield, and DIM; interactions of CP intake with milk lactose yield and DIM; the interaction of NDF intake and milk fat yield; and interactions of starch intake and milk lactose yield, milk fat yield, and DIM (Table 3). When dietary nutrient concentrations, but not intakes, were included in the model, MUN was highly correlated with milk protein yield, milk lactose yield, milk fat yield, SCC, and the interactions of $\mathrm{CP}$, NDF, starch, and $\mathrm{ADF}$ (\% of DM), with milk protein yield, milk lactose yield, milk fat yield, and DIM (Table 4). The effect of BW was not significant in either model. Inclusion of nutrient intakes in the model explained slightly more variation, but the Akaike information criterion (version 9.2; SAS Institute Inc.) increased only from 750 to 758 , suggesting that either approach resulted in similar precision. This is likely due to the high correlation between milk yield and energy intake (Brown et al., 1977; Buttazzoni and Mao, 1989; NRC, 2001). Cow was highly significant in both models.

Having established that MUN can be predicted with comparable precision when nutrient intakes are not known, we used model 2 to analyze the larger field data set (Table 5). As previously observed (Nousiainen et al. 2004) and consistent with the research trial analyses, MUN was highly correlated with dietary CP content. An increase of 1 percentage unit in dietary CP resulted in an increase in MUN of 1.04 and $1.24 \mathrm{mg} / \mathrm{dL}$ for milk yields of 40 and $30 \mathrm{~kg} / \mathrm{d}$, when other parameters in the model were held constant at the mean observed values listed in Table 2. This slope was less than the $1.7 \mathrm{mg} /$ dL observed by Nousiainen et al. (2004). Milk urea N was also associated with dietary NDF, milk yield, and milk protein content and the interactions of dietary $\mathrm{CP}$ with milk yield and milk protein, dietary NDF with DIM and milk protein, and milk yield and milk protein. Cow was highly significant as observed for the research data, and a trend was found for a herd effect $(P<$ $0.08)$. 
Table 4. Parameter estimates for a mixed model relating MUN (mg/dL) to dietary nutrient concentrations, production, and cow factors for the trials summarized in Table 1

\begin{tabular}{|c|c|c|c|}
\hline Item & Estimate & $\mathrm{SE}$ & $P$-value \\
\hline \multicolumn{4}{|l|}{ Effect } \\
\hline Intercept & 16.3 & 1.61 & $<0.0001$ \\
\hline Milk protein yield $(\mathrm{kg} / \mathrm{d})$ & $-1,201$ & 324 & $<0.0004$ \\
\hline Milk lactose yield (kg/d) & 682 & 199 & $<0.001$ \\
\hline Milk fat yield $(\mathrm{kg} / \mathrm{d})$ & 93.9 & 40.1 & $<0.02$ \\
\hline $\mathrm{SCC}(\times 1,000)$ & -0.003 & 0.0009 & $<0.008$ \\
\hline Dietary CP $(\%$ of $\mathrm{DM}) \times$ milk protein yield $(\mathrm{kg} / \mathrm{d})$ & 15.4 & 4.23 & $<0.0006$ \\
\hline Dietary $\mathrm{CP}(\%$ of $\mathrm{DM}) \times$ milk lactose yield $(\mathrm{kg} / \mathrm{d})$ & -9.07 & 2.59 & $<0.0009$ \\
\hline Dietary $\mathrm{CP}(\%$ of $\mathrm{DM}) \times \mathrm{DIM}$ & 0.002 & 0.0009 & $<0.03$ \\
\hline Dietary NDF $(\%$ of DM $) \times$ milk protein yield $(\mathrm{kg} / \mathrm{d})$ & -45.7 & 13.3 & $<0.001$ \\
\hline Dietary NDF $(\%$ of DM) $\times$ milk lactose yield $(\mathrm{kg} / \mathrm{d})$ & 25.9 & 8.22 & $<0.002$ \\
\hline Dietary NDF $(\%$ of DM $) \times$ milk fat yield $(\mathrm{kg} / \mathrm{d})$ & 2.72 & 1.58 & $<0.09$ \\
\hline Dietary NDF $(\%$ of DM $) \times$ DIM & -0.001 & 0.0004 & $<0.01$ \\
\hline Dietary starch $(\%$ of DM $) \times$ milk protein yield $(\mathrm{kg} / \mathrm{d})$ & 28.6 & 8.03 & $<0.0007$ \\
\hline Dietary starch $(\%$ of DM $) \times$ milk lactose yield $(\mathrm{kg} / \mathrm{d})$ & -16.2 & 4.94 & $<0.002$ \\
\hline Dietary starch $(\%$ of $\mathrm{DM}) \times$ milk fat yield $(\mathrm{kg} / \mathrm{d})$ & -2.40 & 1.24 & $<0.06$ \\
\hline Dietary ADF $(\%$ of $\mathrm{DM}) \times$ milk protein yield $(\mathrm{kg} / \mathrm{d})$ & 81.4 & 23.2 & $<0.0008$ \\
\hline Dietary $\mathrm{ADF}(\%$ of $\mathrm{DM}) \times$ milk lactose yield $(\mathrm{kg} / \mathrm{d})$ & -46.0 & 14.3 & $<0.002$ \\
\hline Dietary ADF $(\%$ of $\mathrm{DM}) \times$ milk fat yield $(\mathrm{kg} / \mathrm{d})$ & -5.72 & 2.73 & $<0.04$ \\
\hline \multicolumn{4}{|l|}{ Random effect } \\
\hline Cow & & & $<0.008$ \\
\hline Model precision ${ }^{1}$ & & & Value \\
\hline $\mathrm{AIC}$ & & & 758 \\
\hline RMSE & & & 2.16 \\
\hline
\end{tabular}

${ }^{1} \mathrm{AIC}=$ Akaike information criterion; RMSE $=$ root mean square error.

\section{DISCUSSION}

Urea excretion is ultimately determined by the balance of $\mathrm{N}$ intake and $\mathrm{N}$ deposited in body and milk protein. Nitrogen intake in excess of deposition is converted to urea by the liver and released into blood. Because BUN concentrations are reflective of urea production by the liver, BUN and MUN are indicative of protein balance and thus useful for dietary protein management (Oltner and Wiktorsson, 1983; Broderick and Clayton, 1997). A variety of factors are known to contribute to excess urea $\mathrm{N}$ production, a key being excessive protein or $\mathrm{N}$ consumption. Excessive protein consumption can be caused by greater than expected DMI, deviations in forage protein, an improperly balanced ration, and improper mixing of the ration. Inadequate fermentable or total energy in the diet could fail to support the energy needs of the cow, causing lower than expected milk production. Dehydration will also result in increased BUN and MUN (Weeth and Lesperance, 1965; Steiger Burgos et al., 2001). Other factors that affect MUN but likely have little effect on urea $\mathrm{N}$ excretion include DIM and breed (Broderick and Clayton, 1997; Kauffman and St-Pierre, 2001). Although BW has previously been observed to affect MUN, we did not observe a similar relationship herein (Oltner et al., 1985; Broderick and Clayton, 1997).
Milk urea nitrogen levels in the research trial data were highly correlated with dietary nutrients, production characteristics, and stage of lactation regardless

Table 5. Parameter estimates for a mixed model relating MUN concentration $(\mathrm{mg} / \mathrm{dL})$ to dietary nutrients, cow, and herd factors for the data summarized in Table 2

\begin{tabular}{|c|c|c|c|}
\hline Item & Estimate & $\mathrm{SE}$ & $P$-value \\
\hline \multicolumn{4}{|l|}{ Effect } \\
\hline Intercept & -166 & 26 & $<0.002$ \\
\hline Dietary CP (\% of DM) & 5.4 & 1.1 & $<0.0001$ \\
\hline Dietary NDF ( $\%$ of DM) & 2.84 & 0.45 & $<0.0001$ \\
\hline Milk yield (kg/d) & 0.66 & 0.12 & $<0.0001$ \\
\hline Milk protein (\%) & 37.7 & 7.3 & $<0.0001$ \\
\hline $\mathrm{CP} \times \mathrm{NDF}$ & -0.038 & 0.018 & $<0.03$ \\
\hline $\mathrm{CP} \times$ milk yield & -0.0194 & 0.0057 & $<0.001$ \\
\hline $\mathrm{CP} \times$ milk protein & -0.73 & 0.24 & $<0.003$ \\
\hline $\mathrm{NDF} \times \mathrm{DIM}$ & -0.00005 & 0.00002 & $<0.009$ \\
\hline $\mathrm{NDF} \times$ milk protein & -0.65 & 0.11 & $<0.0001$ \\
\hline Milk $\times$ milk protein & -0.073 & 0.023 & $<0.002$ \\
\hline \multicolumn{4}{|l|}{ Random effect } \\
\hline Herd & & & $<0.08$ \\
\hline Cow(herd) & & & $<0.0001$ \\
\hline \multicolumn{3}{|l|}{ Model precision ${ }^{1}$} & Value \\
\hline AIC & & & 6,959 \\
\hline RMSE & & & 2.42 \\
\hline
\end{tabular}


of whether DMI was considered in the model. Precision analysis of both models indicates that inclusion of nutrient intake explains only slightly more variation in MUN than simply considering dietary nutrient concentrations, supporting the management practice of adjusting dietary protein concentrations to achieve changes in MUN. It also supports the use of data from herds with unknown DMI to assess herd variation in MUN.

On the basis of the results from the field trial (Figure 1 ), the average herd with cows producing between 30 and $40 \mathrm{~kg}$ of milk/d would have MUN concentrations below $12 \mathrm{mg} / \mathrm{dL}$ only if diets contained less than $16 \% \mathrm{CP}$. However, the effect of herd trended to significance $(P$ $<0.08$ ). Least squares means for MUN by herd ranged from a low of $13.6 \mathrm{mg} / \mathrm{dL}$ to a high of $17.3 \mathrm{mg} / \mathrm{dL}$. On the basis of an estimated slope of $1.1 \mathrm{mg} / \mathrm{dL}$ per unit of dietary CP (Figure 1), the herd with the highest MUN would have to reduce dietary CP BY approximately 4.8 percentage units to achieve an MUN of $12 \mathrm{mg} / \mathrm{dL}$ if all other factors are held constant. The diet would need to be $12.8 \% \mathrm{CP}$ based on the average observed dietary CP for that herd. It seems unlikely that such a low level of $\mathrm{CP}$ could be fed without compromising milk production (NRC, 2001). Of course, other management factors not considered in the regression analyses may also explain such a deviation from the norm; thus, one should assess all aspects of the operation before resorting to reduced protein feeding to achieve an MUN goal.
The significant effect of cow in the research and field trials is clear evidence of phenotypic differences in MUN concentrations among cows that are not explained by $\mathrm{N}$ intake, milk yield, BW, or other production-related factors. Mitchell et al. (2005) observed that MUN concentrations were heritable; thus, a genetic component to the observed variation exists. Urea transporters exist in several tissues, including the kidney (Yang et al., 2002) and rumen wall (Stewart et al., 2005), and more than 1 allele for the gene exists (You et al., 1993; Marini and Van Amburgh, 2003; Marini et al., 2004). Genetic variation in these transporters could result in variable transport activity that may explain the observed variation in MUN. If an allele codes for a transporter with reduced activity, this would result in elevated concentrations, and the reverse is true for alleles that code for increased transport activity.

Phenotypic effects on MUN concentrations are potentially problematic from a regulatory standpoint. Environmental or genetic variance may predispose a herd to abnormally high MUN levels even when the herd is following protein feeding guidelines. Attempting to reduce MUN levels to achieve a static regulatory MUN target in such a herd may result in lost production. If MUN is elevated because of low blood urea transport to urine, these cows will be excreting no more urinary $\mathrm{N}$ than cows with more active urea transporters when fed the same diet. Such variation would not be accommodated in the current excretion models (Jonker et al., 1998;

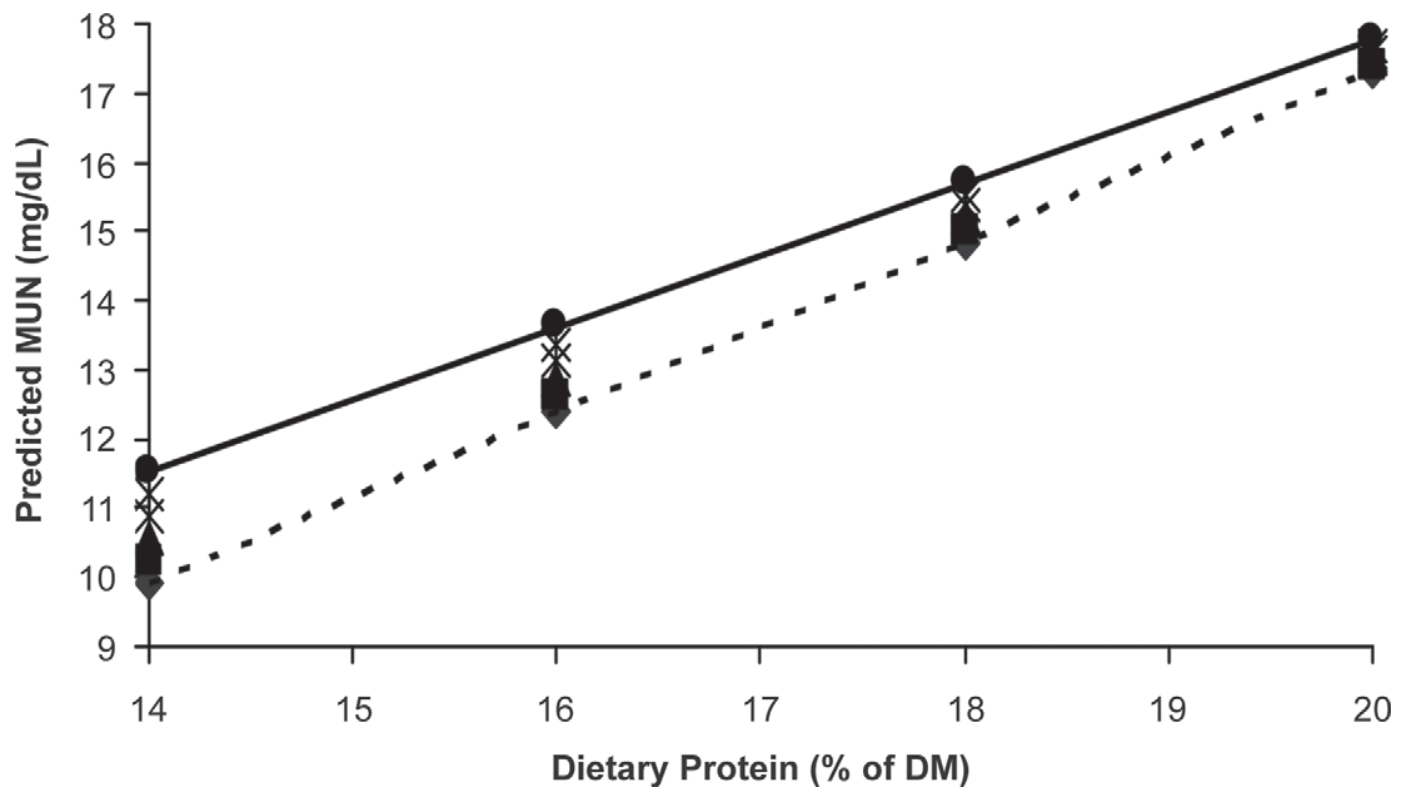

Figure 1. Least squares means estimates for MUN versus dietary CP predicted from the model summarized in Table 5 with varying milk yield, and the observed mean inputs for milk protein, dietary NDF, and DIM set to values listed in Table $2: 30 \mathrm{~kg}$ of milk/d ( $), 32 \mathrm{~kg}$ of milk/d

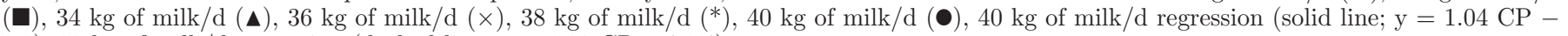
$3.0), 30 \mathrm{~kg}$ of milk/d regression (dashed line; $\mathrm{y}=1.23 \mathrm{CP}-7.34$ ). 
Kauffman and St-Pierre, 2001), and producers may be penalized for failing to meet target levels even though their cows are not excreting any more $\mathrm{N}$ than herds with lower MUN. In the absence of selection measures, a producer may have inadvertently selected for a herd of cows that are predisposed to elevated MUN concentrations. Therefore, target values for MUN should not be used across herds without calibration for each herd unless some accommodation for normal herd variation is considered. If a common target value is to be used across herds, a safety margin should be included to accommodate those herds with intrinsically high MUN. Variation in MUN for herds that participated in the field trial was $1.6 \pm 1.1 \mathrm{mg} / \mathrm{dL}$. On the basis of this estimate, the target MUN level should be set 1.6 units above the population mean from the prediction models to accommodate intrinsic MUN variation. This should ensure that $83 \%$ of well-managed herds can achieve the goal if well managed regardless of their genetic selections. However, the estimate of herd variance was calculated from only 6 herds, which limits the precision of the value, as evidenced by the large standard deviation.

Herd calibration could be achieved through an assessment of the herd feeding program, taking into account all possible factors that may affect the observed variation in MUN. If the herd is well managed and feeding a balanced diet that does not exceed NRC (2001) requirements for protein and has adequate energy, the prevailing MUN could serve as a calibrated target value for that herd. If the herd is overfeeding protein relative to energy supply and milk production, the ration would have to be rebalanced and fed for a period of 2 or 3 weeks before reassessing MUN. The MUN value achieved after this period of feeding to requirements should reflect the calibrated target for the herd. Having determined a herd target value, deviations in MUN above the target would be indicative of overfeeding protein, whereas deviations below the target MUN may indicate that cows are being underfed protein. In the absence of such calibration, some accommodation for variation associated with the cow should be considered when setting guidelines for acceptable MUN values.

\section{REFERENCES}

AOAC International. 1996. Official Methods of Analysis. 16th ed. AOAC Int., Gaithersburg, MD.

AOAC International. 1997. Official Methods of Analysis. 16th ed. AOAC Int., Gaithersburg, MD.

AOAC International. 2000. Official Methods of Analysis. 17th ed. AOAC Int., Gaithersburg, MD.

Bequette, B. J., M. D. Hanigan, H. Lapierre, and J. P. F. D'Mello. 2003. Mammary uptake and metabolism of amino acids by lactating ruminants. Pages 347-365 in Amino Acids in Farm Animal Nutrition. 2nd ed. CABI Publishing, Wallingford, UK.
Boesch, D. F., R. B. Brinsfield, and R. E. Magnien. 2001. Chesapeake Bay eutrophication: Scientific understanding, ecosystem restoration, and challenges for agriculture. J. Environ. Qual. 30:303-320.

Broderick, G. A., and M. K. Clayton. 1997. A statistical evaluation of animal and nutritional factors influencing concentrations of milk urea nitrogen. J. Dairy Sci. 80:2964-2971.

Brown, C. A., P. T. Chandler, and J. B. Holter. 1977. Development of predictive equations for milk yield and dry matter intake in lactating cows. J. Dairy Sci. 60:1739-1754.

Burgos, S. A., J. G. Fadel, and E. J. DePeters. 2007. Prediction of ammonia emission from dairy cattle manure based on milk urea nitrogen: Relation of milk urea nitrogen to urine urea nitrogen excretion. J. Dairy Sci. 90:5499-5508.

Buttazzoni, L., and I. L. Mao. 1989. Genetic parameters of estimated net energy efficiencies for milk production, maintenance, and body weight change in dairy cows. J. Dairy Sci. 72:671-677.

Cyriac, J., A. G. Rius, M. L. McGilliard, R. E. Pearson, B. J. Bequette, and M. D. Hanigan. 2008. Lactation performance of midlactation dairy cows fed ruminally degradable protein at concentrations lower than national research council recommendations. J. Dairy Sci. 91:4704-4713.

DePeters, E. J., and J. P. Cant. 1992. Nutritional factors influencing the nitrogen composition of bovine milk: A review. J. Dairy Sci. 75:2043-2070.

Fisher, D. C., and M. Oppenheimer. 1991. Atmospheric nitrogen deposition and the Chesapeake Bay estuary. Ambio 20:102-108.

Godden, S. M., K. D. Lissemore, D. F. Kelton, K. E. Leslie, J. S. Walton, and J. H. Lumsden. 2001. Relationships between milk urea concentrations and nutritional management, production, and economic variables in Ontario dairy herds. J. Dairy Sci. 84:11281139.

Huhtanen, P., and A. N. Hristov. 2009. A meta-analysis of the effects of dietary protein concentration and degradability on milk protein yield and milk $\mathrm{N}$ efficiency in dairy cows. J. Dairy Sci. 92:3222-3232.

Huntington, G. B., and S. L. Archibeque. 2000. Practical aspects of urea and ammonia metabolism in ruminants. J. Anim. Sci. 77(ESuppl.):1-11.

Jonker, J. S., R. A. Kohn, and R. A. Erdman. 1998. Using milk urea nitrogen to predict nitrogen excretion and utilization efficiency in lactating dairy cows. J. Dairy Sci. 81:2681-2692.

Kauffman, A. J., and N. R. St-Pierre. 2001. The relationship of milk urea nitrogen to urine nitrogen excretion in Holstein and Jersey cows. J. Dairy Sci. 84:2284-2294.

Licitra, G., T. M. Hernandez, and P. J. VanSoest. 1996. Standardization of procedures for nitrogen fractionation of ruminant feeds. Anim. Feed Sci. Technol. 57:347-358.

Marini, J. C., J. D. Klein, J. M. Sands, and M. E. Van Amburgh. 2004. Effect of nitrogen intake on nitrogen recycling and urea transporter abundance in lambs. J. Anim. Sci. 82:1157-1164.

Marini, J. C., and M. E. Van Amburgh. 2003. Nitrogen metabolism and recycling in Holstein heifers. J. Anim. Sci. 81:545-552.

Miglior, F., A. Sewalem, J. Jamrozik, J. Bohmanova, D. M. Lefebvre, and R. K. Moore. 2007. Genetic analysis of milk urea nitrogen and lactose and their relationships with other production traits in Canadian Holstein cattle. J. Dairy Sci. 90:2468-2479.

Mitchell, R. G., G. W. Rogers, C. D. Dechow, J. E. Vallimont, J. B. Cooper, U. Sander-Nielsen, and J. S. Clay. 2005. Milk urea nitrogen concentration: Heritability and genetic correlations with reproductive performance and disease. J. Dairy Sci. 88:4434-4440.

NRC. 2001. Nutrient Requirements of Dairy Cattle. Natl. Acad. Sci., Washington, DC.

NRC. 2003. Air Emissions from Animal Feeding Operations: Current Knowledge, Future Needs. Natl. Acad. Sci., Washington, DC.

Natural Resources Conservation Service. 2011. Conservation Practice Standard: Feed Management. Code 592. USDA, Washington, DC.

Nousiainen, J., K. J. Shingfield, and P. Huhtanen. 2004. Evaluation of milk urea nitrogen as a diagnostic of protein feeding. J. Dairy Sci. 87:386-398.

Oltner, R., M. Emanuelson, and H. Wiktorsson. 1985. Urea concentrations in milk in relation to milk yield, live weight, lactation number 
and amount and composition of feed given to dairy cows. Livest. Prod. Sci. 12:47-57.

Oltner, R., and H. Wiktorsson. 1983. Urea concentrations in milk and blood as influenced by feeding varying amounts of protein and energy to dairy cows. Livest. Prod. Sci. 10:457-467.

Parker, D. S., M. A. Lomax, C. J. Seal, and J. C. Wilton. 1995. Metabolic implications of ammonia production in the ruminant. Proc. Nutr. Soc. 54:549-563.

Preston, R. L., D. D. Schnakenberg, and W. H. Pfander. 1965. Protein utilization in ruminants: I. blood urea nitrogen as affected by protein intake. J. Nutr. 86:281-288.

Rius, A. G., M. L. McGilliard, C. A. Umberger, and M. D. Hanigan. 2010. Interactions of energy and predicted metabolizable protein in determining nitrogen efficiency in the lactating dairy cow. J. Dairy Sci. 93:2034-2043.

Steiger Burgos, M., M. Senn, F. Sutter, M. Kreuzer, and W. Langhans. 2001. Effect of water restriction on feeding and metabolism in dairy cows. Am. J. Physiol. Regul. Integr. Comp. Physiol. 280:R418-R427.

Stewart, G. S., C. Graham, S. Cattell, T. P. L. Smith, N. L. Simmons, and C. P. Smith. 2005. UT-B is expressed in bovine rumen: Potential role in ruminal urea transport. Am. J. Physiol. Regul. Integr. Comp. Physiol. 289:R605-R612.

Stoop, W. M., H. Bovenhuis, and J. A. M. van Arendonk. 2007. Genetic parameters for milk urea nitrogen in relation to milk production traits. J. Dairy Sci. 90:1981-1986.
Tamminga, S. 1979. Protein degradation in the forestomachs of ruminants. J. Anim. Sci. 49:1615-1630.

Tamminga, S. 1992. Nutrition management of dairy cows as a contribution to pollution control. J. Dairy Sci. 75:345-357.

Van Horn, H. H., G. L. Newton, and W. E. Kunkle. 1996. Ruminant nutrition from an environmental perspective: Factors affecting whole-farm nutrient balance. J. Anim. Sci. 74:3082-3102.

Van Soest, P. J., J. B. Robertson, and B. A. Lewis. 1991. Methods for dietary fiber, neutral detergent fiber, and nonstarch polysaccharides in relation to animal nutrition. J. Dairy Sci. 74:3583-3597.

Wattiaux, M. A., E. V. Nordheim, and P. Crump. 2005. Statistical evaluation of factors and interactions affecting dairy herd improvement milk urea nitrogen in commercial Midwest dairy herds. J. Dairy Sci. 88:3020-3035.

Weeth, H. J., and A. L. Lesperance. 1965. Renal function of cattle under various water and salt loads. J. Anim. Sci. 24:441-447.

Wood, G. M., P. J. Boettcher, J. Jamrozik, G. B. Jansen, and D. F. Kelton. 2003. Estimation of genetic parameters for concentrations of milk urea nitrogen. J. Dairy Sci. 86:2462-2469.

Yang, B., L. Bankir, A. Gillespie, C. J. Epstein, and A. S. Verkman. 2002. Urea-selective concentrating defect in transgenic mice lacking urea transporter UT-B. J. Biol. Chem. 277:10633-10637.

You, G., C. P. Smith, Y. Kanai, W. S. Lee, M. Stelzner, and M. A Hediger. 1993. Cloning and characterization of the vasopressinregulated urea transporter. Nature 365:844-847. 